\title{
Irrigation and Fertilization Effects on Nantucket Pine Tip Moth (Lepidoptera: Tortricidae) Damage Levels and Pupal Weight in an Intensively-Managed Pine Plantation ${ }^{1,2}$
}

\author{
David R. Coyle, John T. Nowak ${ }^{3}$ and Christopher J. Fettig ${ }^{4}$ \\ USDA Forest Service, Southern Research Station, P.O. Box 700, New Ellenton, SC 29809 USA
}

\section{J. Entomol. Sci. 38(4): 621-630 (October 2003)}

\begin{abstract}
The widespread application of intensive forest management practices throughout the southeastern U.S. has increased loblolly pine, Pinus taeda L., yields and shortened conventional rotation lengths. Fluctuations in Nantucket pine tip moth, Rhyacionia frustrana (Comstock), population density and subsequent damage levels have been linked to variations in management intensity. We examined the effects of two practices, irrigation and fertilization, on $R$. frustrana damage levels and pupal weights in an intensively-managed $P$. taeda plantation in South Carolina. Trees received intensive weed control and one of the following treatments: irrigation only, fertilization only, irrigation + fertilization, or control. Mean whole-tree tip moth damage levels ranged from $<1$ to $48 \%$ during this study. Damage levels differed significantly among treatments in two tip moth generations in 2001, but not 2000 . Pupal weight was significantly heavier in fertilization compared to the irrigation treatment in 2000 , but no significant differences were observed in 2001. Tree diameter, height, and aboveground volume were significantly greater in the irrigation + fertilization than in the irrigation treatment after two growing seasons. Our data suggest that intensive management practices that include irrigation and fertilization do not consistently increase $R$. frustrana damage levels and pupal weights as is commonly believed. However, tip moth suppression efforts in areas adjacent to our study may have partially reduced the potential impacts of $R$. frustrana on this experiment.
\end{abstract}

Key Words Growth impacts, intensive forestry, pine regeneration insects, Pinus taeda, Rhyacionia frustrana, silviculture

The Nantucket pine tip moth, Rhyacionia frustrana (Comstock), is an important insect pest of juvenile pines (Berisford 1988, Asaro et al. 2003). Rhyacionia frustrana completes two to five generations annually depending on the geographic location and associated climatic conditions. Three or four generations per year are most common throughout the major pine producing regions of the southeastern U.S. (Fettig et al. 2000). Female moths deposit eggs singly on needles and shoots of young trees. Neonates mine the needles, while late instars enter the lateral and terminal shoots where their feeding severs the vascular tissue and kills the apical meristem. Fifth instars pupate and overwinter in the damaged shoots. Larval feeding can cause shoot

\footnotetext{
${ }^{1}$ Received 07 November 2002; accepted for publication 15 June 2003.

${ }^{2}$ The right of the U.S. Government to retain copyright is accepted. The use of trade names in this publication is solely for reader information and does not imply endorsement by the U.S. Department of Agriculture.

3USDA Forest Service, Forest Health Protection, Asheville, NC 28804.

'USDA Forest Service, Pacific Southwest Research Station, Davis, CA 95616.
} 
mortality and tree deformity (Berisford and Kulman 1967), height and volume reductions (Nowak and Berisford 2000), formation of compression wood (Hedden and Clason 1980), and occasional tree mortality. The tolerance of young trees to $R$. frustrana damage is initially low, but increases with age. Damage is most severe on seedlings and saplings $<5 \mathrm{yr}$ old. Particularly susceptible is loblolly pine, Pinus taeda L., the most commercially important tree species in the southeastern U.S. (Schultz 1999).

Intensively-managed forest plantations now occupy over 14 million ha of timberland in the southeastern U.S. (Guldin and Wigley 1998). Large gains in P. taeda productivity can be achieved with intensive forest management practices such as herbaceous weed control, irrigation and fertilization (Pritchett and Smith 1972, Jokela and Martin 2000, Nowak and Berisford 2000, Borders and Bailey 2001, Retzlaff et al. 2001). However, intensive management has, at times, resulted in an increased frequency and severity of pest infestations (Cade and Hedden 1987, Ross et al. 1990). Conventional wisdom among forest managers asserts that tip moth infestation levels increase with management intensity (Berisford and Kulman 1967, Ross and Berisford 1990). Several studies have specifically investigated the effects of vegetation control and fertilization on tip moth damage levels. Herbicides applied to competing vegetation have been reported to increase (Ross et al. 1990), decrease (McCravy and Berisford 2001) and have inconsistent effects (Miller and Stephen 1983, Nowak and Berisford 2000, Nowak et al. 2003) on R. frustrana population levels depending on when such measurements are taken.

Ross and Berisford (1990) predicted a positive relationship between the amount of nutrients and water available for tree uptake and tip moth infestation levels based on their greenhouse study. However, Pritchett and Smith (1972) found reductions in $R$. frustrana damage levels associated with phosphorus $(P)$ and potassium $(K)$ fertilization, but not nitrogen (N) fertilization. Nowak and Berisford (2000) found no significant differences in $R$. frustrana damage levels related to irrigation or fertilization in a 4-yr study conducted on the Georgia Coastal Plain. Berisford et al. (1989) found reduced $R$. frustrana damage levels associated with fertilization during $1 \mathrm{yr}$ of a $3-\mathrm{yr}$ study. Increased tip moth damage and a greater number of pupae were found in plots receiving both weed control and nitrogen fertilization compared with the control treatment (Nowak et al. 2003). Despite these data, it is widely accepted that tip moth populations increase with management intensity.

According to Yin and Sedjo (2001), forestry has entered the "age of intensive forestry" and, therefore, there is a critical need for studies on the effects of intensive forest management practices on insect pest populations, and specifically $R$. frustrana. In February 2000 a study was established to examine the physiological effects of irrigation and fertilization on above and below ground growth and nutrient allocation in four tree species (Coleman 2001). Due to the experimental nature of the plantation, the levels of site preparation and herbicide applications were more intensive than routine operational management in the southeastern U.S. today. Our objectives were to determine the effects of irrigation and fertilization on $R$. frustrana damage levels, $R$. frustrana pupal weight, and tree growth.

\section{Materials and Methods}

Study location. This study was conducted at the U.S. Department of Energy Savannah River Site, a National Environmental Research Park, located in Aiken Co., 
SC $\left(33^{\circ} 23^{\prime} \mathrm{N}, 81^{\circ} 40^{\prime} \mathrm{E}\right)$. Deep sandy loam soils of the Blanton series dominated the entire 40-ha study site. Surrounding vegetation included mature $P$. taeda and longleaf pine, Pinus palustris Mill., with a sparse upland oak, Quercus spp., understory. Prior to harvest in 1999, the site contained naturally regenerated stands of 12-yr-old $P$. taeda and 36-yr-old $P$. palustris. Site preparation included slash removal, tillage with debris incorporation to a depth of $30 \mathrm{~cm}$, disking, and an application of lime at a rate of $3.4 \mathrm{Mg} /$ ha to increase soil $\mathrm{pH}$ to 6.5 . As part of a larger study (Coleman 2001), four 0.22 -ha study plots in each of three blocks were arranged in a randomized complete block design in spring 2000.

Silvicultural treatments. Pinus taeda $1+0$ seedlings (grown for $1 \mathrm{yr}$ in the nursery prior to outplanting) (family 7-56, International Paper, Lumberton, NC) were hand planted using dibbles in February 2000. Each plot contained 14 rows of 21 trees (294 trees total) planted on a $2.5 \times 3 \mathrm{~m}$ spacing. Annual weed control consisted of oxyflourfen (Goal ${ }^{\circledR 2}$ 2X, Rohm and Haas, Philadelphia, PA) applications at a rate of 4.16 L/ha in January prior to budbreak using a tractor-mounted sprayer (Fimco Inc., Sioux City, IA), and up to four glyphosate (Roundup PRO ${ }^{\circledR}$, Monsanto Corp., St. Louis, $\mathrm{MO}$ ) applications at a rate of $5 \%$ althroughout the growing season via backpack sprayers (Solo ${ }^{*}$, Newport News, VA).

A drip irrigation system provided four silvicultural treatments: irrigation only, fertilization only, irrigation + fertilization, or control. Irrigation and irrigation + fertilization treatments received $3.0-\mathrm{cm}$ water $\mathrm{ha}^{-1} \mathrm{wk}^{-1}$ between 1 April and 31 October 2000 and 2001. Liquid fertilizer (7:7:7 N:P:K plus micronutrients $B, C u, M n, M o$, and $\mathrm{Zn}$ in $2000,7: 5: 8 \mathrm{~N}: P: K$ without micronutrients in 2001) was applied through the drip irrigation system weekly at a rate of $120 \mathrm{~kg} \mathrm{~N}^{-1} \mathrm{ha}^{-1} \mathrm{yr}^{-1}$ from 1 April to 30 September to the fertilization and irrigation + fertilization treatments. The fertilization treatment received $0.5-\mathrm{cm} \mathrm{ha}^{-1}$ of water weekly to facilitate the fertilizer application; therefore, all control trees received this amount of water to maintain experimental consistency among treatments. Tip moth control was provided to all plots with a $3.3 \%[\mathrm{Al}]$ permethrin solution (Ambush ${ }^{\circledR}, 25.6 \%$ [Al], Zeneca Ag Products, Wilmington, DE). Trees were sprayed until foliage was moistened using backpack sprayers with flat fan nozzles. Permethrin was applied according to the optimal spray-timing model for Aiken Co., SC, (Fettig et al. 2000) during the third and fourth $R$. frustrana generations in 2000 and all four generations in 2001. Insecticide applications took place early in the morning to minimize potential spray drift. Two rows of nine trees each (eighteen total trees per plot; study trees were located in the second and twelfth plot rows, and were separated by $30 \mathrm{~m}$ ) were omitted from insecticide treatments and used in our study. Insecticide treatments were not made during the first two $R$. frustrana generations in 2000 due to unrelated events.

Sample methodology. Rhyacionia frustrana damage (defined as the \% of total shoots infested) was evaluated following each of the four generations in 2000 and after generations one, three, and four in 2001. Evaluation dates coincided with either the pupal stage or adult emergence of the subsequent generation. The total number of shoots (i.e., $>10$ linear $\mathrm{cm}$ of apical stem containing foliage) and number of $R$. frustrana damaged shoots was recorded for each study tree.

After the fourth generation in both 2000 and 2001, 150 R. frustrana-damaged shoots from each treatment were collected and returned to the laboratory for further examination. Shoot clippings were limited to two shoots randomly selected from lateral terminals on each tree. Following field collection, each shoot was examined for $R$. frustrana pupae. Apparently healthy and unparasitized female pupae were 
weighed using a Thomas Scientific T200S analytical balance (Setra Systems, Inc., Acton, MA).

Tree basal diameter and height were measured at the conclusion of each growing season. Above-ground volume was calculated as diameter ${ }^{2} \times$ height. $^{-}$

Statistics. Damage levels were analyzed for individual generations. The percentage of damaged shoots on each tree was defined as the number of infested shoots divided by the total number of shoots. These data were subjected to an angular transformation (arcsine square root) prior to analysis (Sokal and Rohlf 1995). For each growing season, tree basal diameter, height, calculated volume, and tip moth pupal weights were subjected to analysis of variance (ANOVA) for a randomized complete block design and compared with the Tukey standardized range test for separation of treatment means (Sokal and Rohlf 1995). PROC GLM (SAS Institute 2000) was used for ANOVA and contrast comparisons of irrigation, fertilization, and the irrigation $\times$ fertilization interaction effects on all measured parameters.

\section{Results and Discussion}

Damage levels. During the 2 yrs in which this study was conducted, tip moth damage levels on individual trees ranged from 0 to $100 \%$. Mean tip moth damage levels (within a treatment) ranged between $<1$ and $47.7 \%$ in 2000 and 5.3 and $44 \%$ in 2001 (Table 1). Average damage levels (combining all treatments) were $<20 \%$ in four of seven generations evaluated in our study, and never exceeded $43 \%$. In general, these infestation rates are lower than reported in previous studies involving intensive pine culture. However, Nowak and Berisford (2000) reported low infestation rates $(<15 \%$ in seven of nine generations evaluated) in herbicide only, herbicide + irrigation, and herbicide + irrigation + fertilization treatments. The application of permethrin, a broad-spectrum insecticide, to all trees except our study trees may have suppressed overall tip moth populations in the area. In addition, the forest habitat surrounding the study area consisted primarily of mature pines. Older trees appear to be more resistant to $R$. frustrana infestation and generally support only small populations (Asaro et al. 2003), and thus offer limited migration potential to adjacent newly-planted sites.

Ross and Berisford (1990) found increased tip moth oviposition on fertilized + irrigated trees in the greenhouse, concluding that similar field treatments would increase tip moth damage levels and pupal weights. Nowak et al. (2003) found no significant differences in tip moth damage related to nitrogen applications over six generations in a 2-yr study. However, Nowak and Berisford (2000) found no increase in tip moth infestation rates as a result of fertilization. Mean tip moth damage levels did not differ significantly among silvicultural treatments in 2000 or in the first tip moth generation of $2001(P>0.05$ in all cases; Table 1$)$ in our study. The extremely low damage levels observed during generation 1 of 2000 likely resulted from a lack of $R$. frustrana recruitment from adjacent areas. Rhyacionia frustrana prefers hosts $<5 \mathrm{yr}$ old (Berisford 1988), and because the surrounding vegetation consisted of mature $P$. taeda and $P$. palustris, the latter a non-host, only limited recruitment may have occurred. However, damage levels did significantly differ among treatments in generations $3(F=4.87$; $d f=3,6 ; P<0.003)$ and 4 of 2001 ( $F=4.33$; df $=3,6$; $P<0.006$; Table 1). Significantly higher damage levels occured in both the irrigation and control treatments compared to the fertilization treatment in generation 3, 2001, and contrast comparisons indicated that significantly lower damage levels were ob- 


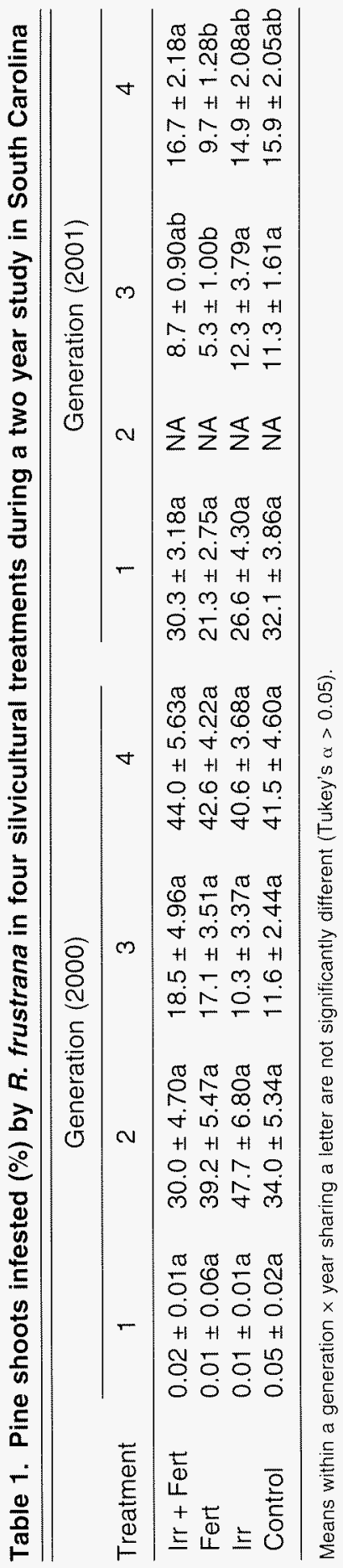


served on fertilized (irrigation + fertilization and fertilization treatments) compared to non-fertilized (irrigation and control treatments) trees $(P<0.01)$. Generation 4, 2001 damage levels were significantly higher in the irrigation + fertilization treatment than in the fertilization treatment.

Pupal weight. Pupal weights in our study ranged from 5.39 to $6.5 \mathrm{mg}$ (Fig. 1). Treatment significantly affected female $R$. frustrana pupal weight in $2000(F=3.55$; $\mathrm{df}=3,6 ; P<0.016)$, but not in $2001(F=0.62$; $\mathrm{df}=3,6 ; P=0.601)$. Contrast comparisons indicated that pupal weights in treatments receiving fertilizer were significantly heavier than in non-fertilized treatments in $2000(F=7.78$; df $=1,6$; $P=0.032$ ). Pupae from trees in the fertilization treatment in 2000 were significantly heavier than those in the irrigation treatment, while pupal weights in the irrigation + fertilization treatment and control did not differ significantly from other treatments (Fig. 1). Ross and Berisford (1990) found the heaviest pupae in fertilized + irrigated trees in a greenhouse study. Conversely, Nowak et al. (2003) observed greater pupal weights in control treatments compared to a fertilizer + weed control treatment.

A comprehensive study by Asaro and Berisford (2001) found that female pupal weights ranged from 7 to $10 \mathrm{mg}$ in the absence of fertilizer in the field. Pupal weight is a function of food quality and quantity, and provides an indication of potential adult fecundity and fitness (Miller 1957, Tisdale and Sappington 2001). Intensively managed pine plantations provide an enormous amount of high quality plant material. This might be expected to lead to increased $R$. frustrana pupal weights, fecundity, and subsequent population levels. However, female pupal weights in our study do not seem to support this hypothesis, although the relationship between $R$. frustrana fecundity and female pupal weight has not been examined in our plantation.

Tree growth. Silvicultural treatment significantly affected $P$, taeda diameter $(F=$ 4.90; $\mathrm{df}=3,6 ; P<0.003)$, height $(F=6.31 ; \mathrm{df}=3,6 ; P<0.001)$, and volume $(F=3.56$; $\mathrm{df}=3,6 ; P<0.017)$ after both growing seasons (Fig. 2$)$. Trees receiving the irrigation

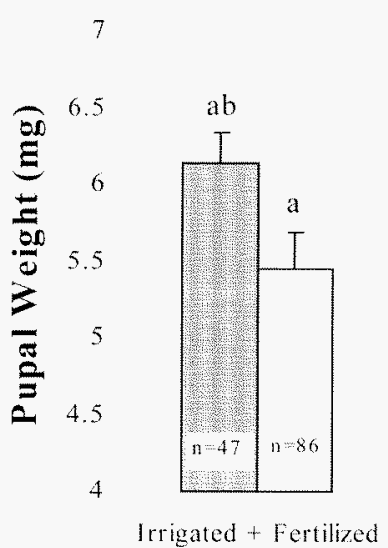

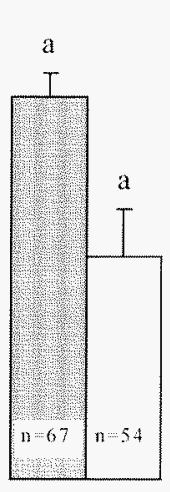

Fertilized

$\square 2000$

$\square 2001$

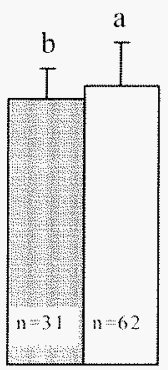

Irrigated

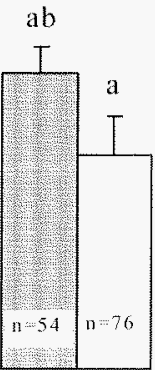

Control

\section{Treatment}

Fig. 1. Female Rhyacionia frustrana pupal weights $(\mathrm{mg})$ collected after generation 4 , 2000 and 2001 . Means within a year sharing a letter are not significantly different (Tukey's, $\alpha>0.05$ ). 

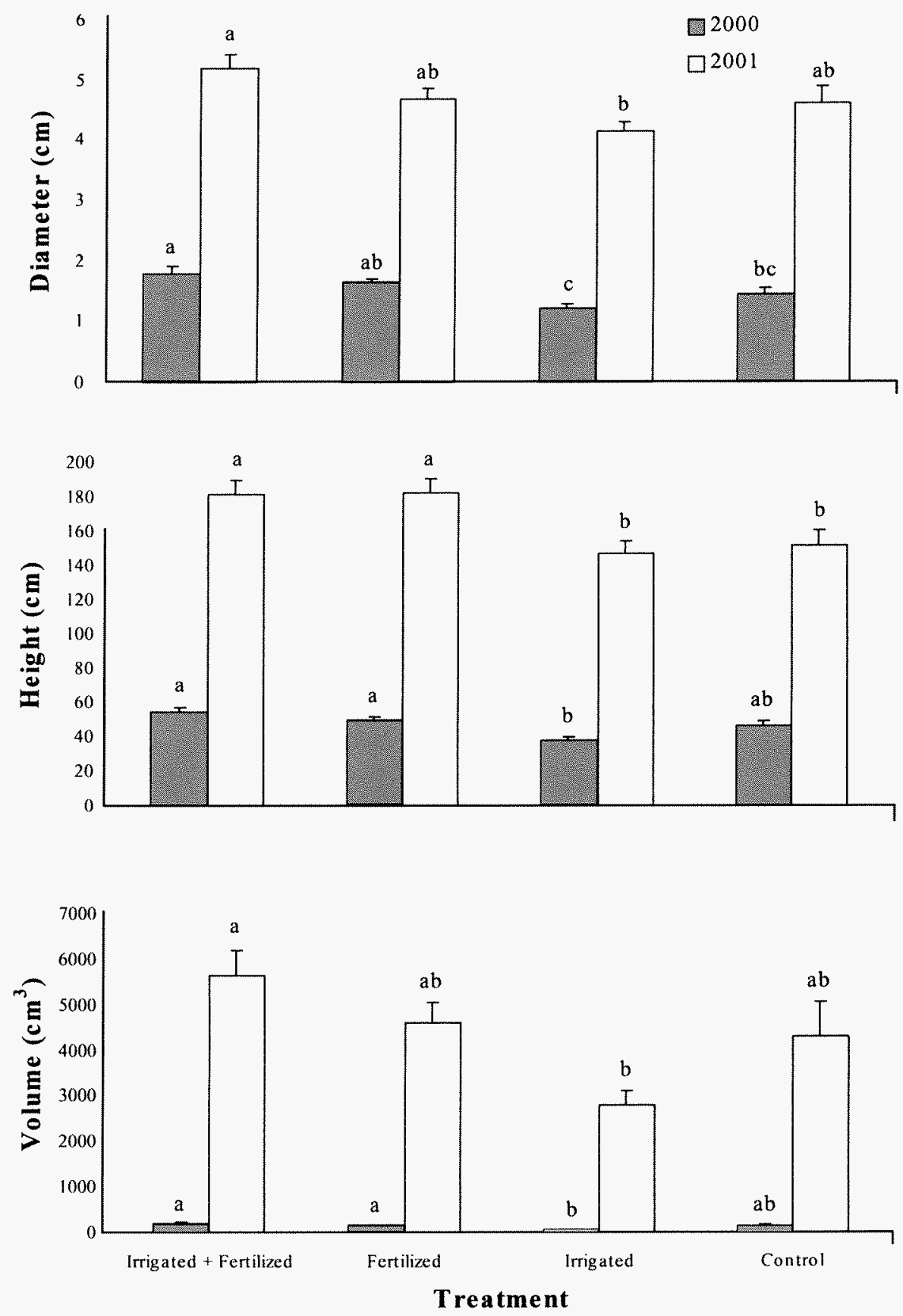

Fig. 2. Pinus taeda growth parameters after two growing seasons in an intensively managed plantation. Means within a year sharing a letter are not significantly different (Tukey's, $\alpha>0.05$ ). 
+ fertilization treatment were larger than those in the irrigation treatment. Contrast comparisons showed that fertilization significantly increased diameter, height, and volume after year one, but only height and volume after year two (Table 2). These results are in agreement with other studies examining the effects of fertilization on $P$. taeda growth in the Southeast (Samuelson 1998, Jokela and Martin 2000, Retzlaff et al. 2001, Yin and Sedjo 2001). Irrigation and fertilization, in addition to weed control, significantly increased tree height and volume after each of the first three growing seasons in the Georgia Coastal Plain (Nowak and Berisford 2000).

Contrast comparisons indicated that irrigation alone did not have a significant effect on tree growth (Table 2). Trees receiving the irrigation treatment were significantly smaller than those receiving the irrigation + fertilization treatment in our study (Fig. 2). Blanton series soils are low in nutrients, and the $0.5 \mathrm{~cm} /$ ha daily water application may have increase nutrient leaching causing soils to become further nutrient deficient. Munson et al. (1993) found that certain aspects of intensive plantation management can increase nutrient leaching. Such inconsistencies in soil type and fertility may explain the unpredictable effect of irrigation on $P$. taeda growth (Albaugh et al. 1998, Samuelson 1998, Maier 2001). Tree volume followed the pattern of irrigated + fertilization $>$ fertilization $>$ control $>$ irrigated in both years (Fig. 2).

Conclusion. The notion that increased management intensity of plantation pine results in elevated $R$. frustrana damage levels and pupal weight has been examined in many studies. Results from this experiment do not concur with or refute this idea, but parallel two recent studies (Nowak and Berisford 2000, Nowak et al. 2003) that illustrate how increased management intensity of plantation pine does not always, but can in some instances, exacerbate $R$. frustrana damage levels. When significant differences occurred in our study, the highest pupal weights and lowest damage levels occurred in the fertilization or irrigation + fertilization compared with the irrigation treatment (with the exception of generation 4, 2001). Fertilization either had no effect or was associated with lower tip moth damage in other field studies (Pritchett and Smith 1972, Berisford et al. 1989, Nowak and Berisford 2000). Our data suggest that fertilization is the most important factor driving $P$. taeda growth and has little impact on $R$. frustrana damage levels and pupal weights. However, one must be cautious when extrapolating our results to the plantation level. While our study contributes information regarding the effects of irrigation and fertilization on $R$. frustrana at the individual tree level, several factors (including surrounding habitat, the insecticide treatment of surrounding trees, and small sample size) make plantation-level

Table 2. Contrast comparisons for $P$. taeda growth parameters after the 2000 and 2001 growing seasons

\begin{tabular}{|c|c|c|c|c|c|c|}
\hline \multirow[b]{2}{*}{ Source } & \multicolumn{3}{|c|}{2000} & \multicolumn{3}{|c|}{2001} \\
\hline & Diameter & Height & Volume & Diameter & Height & Volume \\
\hline Treatment & $* * *$ & $* \star *$ & $* * *$ & * & $* * \star *$ & ** \\
\hline Irrigation & ns & ns & ns & ns & ns & ns \\
\hline Fertilization & $*$ & * & * & ns & * & * \\
\hline$I \times F$ & ns & ns & ns & ns & ns & ns \\
\hline
\end{tabular}

${ }^{* * *}, P<0.001 ;{ }^{* *}, P=0.001$ to $0.009 ;{ }^{*}, P=0.01$ to $0.05 ;$ ns, not significant. 
application of the data questionable. Fertilization in conjunction with irrigation significantly increased $P$. taeda growth and yield. This becomes increasingly important as timber production changes from natural stands to intensively-managed plantations in the Southeast. As the intensity of plantation management increases, so does production (Yin and Sedjo 2001) and presumably pest susceptibility. Further research is necessary to adequately characterize tip moth responses to intensive management in large-scale plantations.

\section{Acknowledgments}

The authors thank R. Garland (University of Georgia, Athens), B. Heitkamp, L. Priest, R. Rose, J. Scott, V. Slater, and L. Williams (USFS, Savannah River) for technical assistance and data collection. We thank C. Asaro (University of Georgia, Athens) and A. Mangini (USFS, Pineville, LA) for a technical review of the manuscript. Special thanks to M. D. Coleman (USFS, Savannah River) for project support. JTN and CJF were supported in part by the Pine Tip Moth Research Consortium (C. W. Berisford, University of Georgia, Athens, Director). Funding for DRC was provided by the Department of Energy-Savannah River Operations office through the Forest Service-Savannah River and the Forest Service Southern Research Station under Interagency Agreement DE-IA09-76SR00056. This project was conducted as part of the Short Rotation Woody Crops Cooperative Research Program, USDA Forest Service, Southern Research Station.

\section{References Cited}

Albaugh, T. J., H. L. Allen, P. M. Dougherty, L. W. Kress and J. S. King. 1998. Leaf area and above- and below-ground growth responses of loblolly pine to nutrient and water additions. For. Sci. 44: 317-328.

Asaro, C. and C. W. Berisford. 2001. Seasonal changes in adult longevity and pupal weight of the Nantucket pine tip moth (Lepidoptera: Tortricidae) with implications for interpreting pheromone trap catch. Environ. Entomol. 30: 999-1005.

Asaro, C., C. J. Fettig, K. W. McCravy, J. T. Nowak and C. W. Berisford. 2003. The Nantucket pine tip moth (Lepidoptera: Tortricidae): a literature review with management implications. J. Entomol. Sci. 38: 1-40.

Berisford, C. W. 1988. The Nantucket pine tip moth, Pp. 141-161. In A. A. Berryman [ed.], Dynamics of Forest Insect Populations. Plenum Publishing Corp. 603 p.

Berisford, C. W. and H. M. Kulman. 1967. Infestation rate and damage by the Nantucket pine tip moth in six loblolly pine stand categories. For. Sci. 13: 428-438.

Berisford, C. W., J. F. Godbee, Jr. and D. W. Ross. 1989. Impact of pine tip moth control, weed control, and fertilizer on growth and form of loblolly pine, Pp. 130-136. In Alfaro, R. I. and S. G. Golver [eds.], Insects Affecting Reforestation: Biology and Damage. Proc. IUFRO Working Group: Insects Affecting Reforestation. Forestry Canada, Pacific Forestry Centre, Vancouver, BC, Canada.

Borders, B. E. and R. L. Bailey. 2001. Loblolly pine-pushing the limits of growth. South J. Appl. For. 25: 69-74.

Cade, S. C. and R. L. Hedden. 1987. Growth impact of pine tip moth on loblolly pine plantations in the Ouachita Mountains of Arkansas. South. J. Appl. For. 11: 128-133.

Coleman, M. D. 2001. Short rotation woody crop cooperative research program, Pp. 3-12. In T. A. Volk, L. P. Abrahamson, and J. L. Ballard (comps.), Proceedings of the Short-Rotation Woody Crops Operations Working Group, Third Conference. 10-13 October 2000, Syracuse, NY. 200 p.

Fettig, C. J., M. J. Dalusky and C. W. Berisford. 2000. Nantucket pine tip moth phenology and timing of insecticide spray applications in seven Southeastern States. Res. Pap. SRS-18. 
Asheville, NC: U.S. Department of Agriculture, Forest Service, Southern Research Station. $21 \mathrm{p}$.

Guldin, J. M. and T. B. Wigley. 1998. Intensive management-can the South really live without it? Trans. 63rd North Am. Wildl. and Natur. Resour. Conf. 20-25 March 1998, Orlando, FL. Washington, D.C. Wildife Management Institute: 362-365.

Hedden, R. L. and T. Clason. 1980. Nantucket pine tip moth impact on loblolly pine wood and product quality. Forest Research Report 1979. Homer, Louisiana: Louisiana State University Agricultural Experiment Station. $9 \mathrm{p}$.

Jokela, E. J. and T. A. Martin. 2000. Effects of ontogeny and soil nutrient supply on production, allocation, and leaf area efficiency in loblolly and slash pine stands. Can. J. For. Res. 30: $1511-1524$.

Maier, C. A. 2001. Stem growth and respiration in loblolly pine plantations differing in soil resource availability. Tree Physiol. 21: 1183-1193.

McCravy, K. M. and C. W. Berisford. 2001. Effects of vegetation control on parasitoids of the Nantucket pine tip moth, Rhyacionia frustrana (Lepidoptera: Tortricidae). Florida Entomol. 84: 282-287.

Miller, V. A. 1957. A technique for estimating the fecundity of natural populations of the spruce budworm. Can. J. Zool. 35: 1-13.

Miller, F. D., Jr. and F. M. Stephen. 1983. Effects of competing vegetation on Nantucket pine tip moth (Lepidoptera: Tortricidae) populations in loblolly pine plantations in Arkansas. Environ. Entomol. 12: 101-105.

Munson, A. D., H. A. Margolis and D. G. Brand. 1993. Intensive silvicultural treatment: impacts on soil fertility and planted conifer response. Soil. Sci. Soc. Am. J. 57: 246-255.

Nowak, J. T. and C. W. Berisford. 2000. Effects of intensive forest management practices on insect infestation levels and loblolly pine growth. J. Econ. Entomol. 93: 336-341.

Nowak, J. T., T. B. Harrington and C. W. Berisford. 2003. Nantucket pine tip moth development and population dynamics: influence of nitrogen fertilization and vegetation control. For. Sci. 49: 731-737.

Pritchett, W. L. and W. H. Smith. 1972. Fertilizer responses in young pine plantations. Soil Sci. Soc. Am. Proc. 36: 660-663.

Retzlaff, W. A., J. A. Handest, D. M. O'Malley, S. E. McKeand and M. A. Topa. 2001. Wholetree biomass and carbon allocation of juvenile trees of loblolly pine (Pinus taeda): influence of genetics and fertilization. Can. J. For. Res. 31: 960-970.

Ross, D. W. and C. W. Berisford. 1990. Nantucket pine tip moth (Lepidoptera: Tortricidae) response to water and nutrient status of loblolly pine. For. Sci. 36: 719-733.

Ross, D. W., C. W. Berisford and J. F. Godbee, Jr. 1990. Pine tip moth, Rhyacionia spp., response to herbaceous vegetation control in an intensively site-prepared loblolly pine plantation. For. Sci. 36: 1105-1118.

Samuelson, L. J. 1998. Influence of intensive culture on leaf net photosynthesis and growth of sweetgum and loblolly pine seedlings. For. Sci. 44: 308-316.

SAS Institute. 2000. User's guide: statistics, version 8.1. SAS Institute, Cary, NC.

Schultz, R. P. 1999. Loblolly-the pine for the twenty-first century. New For. 17: 71-88.

Sokal, R. R. and F. J. Rohlf. 1995. Biometry, 3rd ed. W. H. Freeman \& Co., New York. 887 p.

Tisdale, R. A. and T. W. Sappington. 2001. Realized and potential fecundity, egg fertility, and longevity of laboratory-reared female beet armyworm (Lepidoptera: Noctuidae) under different adult diet regimes. Ann. Entomol. Soc. Am. 94: 415-419.

Yin, R. and R. A. Sedjo. 2001. Is this the age of intensive management? A study of loblolly pine on Georgia's piedmont. J. For. 99: 10-17. 